\title{
MICROWAVE DRYING CHARACTERISTICS FOR GINGER ROOT (Zingiber officinale)
}

\author{
Taha, A. T."
}

\section{ABSTRACT}

This experiment was carried out at Agricultural Engineering Department Minofiya University to study microwave drying characteristics for ginger root. Five microwave drying powers (180, 360, 540, 720 and 900 Watt) and four levels of ginger thickness $(0.5,1,1.5$ and $2 \mathrm{~cm})$ were used. Drying characteristics and quality aspects of the dried ginger were studied. The drying time to achieve the save storage moisture content was 14 minutes at 900 Watt with $0.5 \mathrm{~cm}$ thickness. Total phenolic content of fresh ginger was $0.40 \mathrm{mg} / \mathrm{g} . \mathrm{d} . \mathrm{m}$. and the highest phenol content in dried ginger was detected at the 900 Watt power with $1.5 \mathrm{~cm}$ thickness, and the lowest phenolic value was recorded at 180 Watt with $2 \mathrm{~cm}$ thickness. The fresh ginger hardness ranged from 0.5 to $1 \mathrm{~kg} / \mathrm{cm}^{2}$ and the highest hardness of dried ginger was $6 \mathrm{~kg} / \mathrm{cm}^{2}$ at both 720 and 900 $W$ with all thickness. The highest drying efficiency of ginger slices was $78 \%$ at 720 and 900 Watt with $2 \mathrm{~cm}$ thickness and the lowest efficiency (less than 10\%) was recorded at 180 Watt with all used thicknesses (except at $2 \mathrm{~cm}$. thickness). The highest value of energy consumption (10.2 MJ) was detected at 180 Watt and $2 \mathrm{~cm}$ thickness, while drying at 900 Watt with both 0.5 and $1 \mathrm{~cm}$. thickness represent the lowest energy consumption $(1.13 \mathrm{MJ})$. Veirma model can be used to describe the behavior of microwave drying of ginger, which gave the best results.

Key word: microwave, drying, ginger, thickness

\section{1-INTRODUCTION}

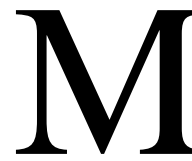
icrowave energy can be used to reduce the drying time, which is rapidly absorbed by the product water molecules and consequently results in rapid evaporation of water and thus higher drying rates. The interior temperature of dried microwave-heated food is higher than the surface temperature and moisture is transferred to the surface more dynamically than during convective drying (Torringa et al., 2001).

\footnotetext{
* Agricultural Engineering Department, Faculty of Agric., Menoufia University.
} 
Chan, et al. (2008) studied the effects of different drying methods on the antioxidant properties of leaves and tea of ginger species Microwavedrying of elation leaves resulted in significant losses in total phenolic compound and antioxidant but the declines were comparable between different drying durations.

Ginger products have varied applications in culinary preparation, bakery products, toiletry products, perfume industries, meat products, and soft drinks making. Dried ginger is used both as a spice and medicine. It contains an essential oil, which imparts an aroma, an oleoresin responsible for the pungent smell, starch, gums, proteins, carbohydrate, mineral matter, and fiber Rahman, et al. (2009).

A microwave drying at a constant temperature usually follows a typical drying curve. In the middle drying stage, moisture is rapidly removed, large amount of aroma is lost, and charring often occurs Li et al. (2010). Also, 'Puffing' usually happens in this stage, causing quality damage and undesirable changes in the food texture Zhang et al. (2006).

The overall aim of this research was:

- Evaluate the microwave drying technique,

- Study the relation between microwave power, ginger thickness and drying load on dried ginger properties

\section{2-MATERIALS AND METHODS}

\section{Materials:}

Fresh ginger (Zingiber officinal's) was purchased from locale market in Shibin El- Kom, Egypt. Manually recapped and sorted then cut to four thicknesses $(0.5,1,1.5$ and $2 \mathrm{~cm}$.)

\section{Microwave oven dryer (KOR-9G2B)}

Microwave oven (KOR-9G2B) with maximum output of $900 \mathrm{~W}$ and 2450 $\mathrm{MHz}$ was used for drying experiments. The outside dimensions of the microwave were $465 * 280 * 282 \mathrm{~mm}$. cavity dimensions $\left(\mathrm{W} * \mathrm{H}^{*} \mathrm{D}\right)$ $314 * 235 * 346 \mathrm{~mm}$ and cavity volume $26 \mathrm{~L}$, Net weight approx. $11 \mathrm{~kg}$, Timer 59 min., 90 sec., Power selections 10 levels with one dish with diameter $30 \mathrm{~cm}$. 


\section{Methods:}

\section{Ginger preparation:}

Ginger roots (Zingiber officinal's) were washed with cold water manually recapped and sorted then cut to four thicknesses $(0.5,1,1.5$ and $2 \mathrm{~cm}$.) using a knife. Ginger slices was spread (single layer) with a near uniform distribution density on the mesh trays of the drying chambers for drying. The moisture content of ginger measured by putting them in the drying oven for 24 hours at $70{ }^{\circ} \mathrm{C}$.

\section{Table 1. Nutritional composition of ginger (per 100g). According to Shirin and Prakash (2010)}

\begin{tabular}{|l|l|l|l|}
\hline Constituent & Value & Constituent & Value \\
\hline Moisture & $15.02 \pm 0.04$ & Ash $(\mathrm{g})$ & $3.85 \pm 0.61(4.53)$ \\
\hline Protein $(\mathrm{g})$ & $5.087 \pm 0.09(5.98)$ & Calcium $(\mathrm{mg})$ & $88.4 \pm 0.97(104.02)$ \\
\hline Fat $(\mathrm{g})$ & $3.72 \pm 0.03(4.37)$ & Phosphorous $(\mathrm{mg})$ & $174 \pm 1.2(204.75)$ \\
\hline Insoluble fiber $(\%)$ & $23.5 \pm 0.06(27.65)$ & Iron $(\mathrm{mg})$ & $8.0 \pm 0.2(9.41)$ \\
\hline Soluble fibre $(\%)$ & $25.5 \pm 0.04(30.0)$ & Zinc $(\mathrm{mg})$ & $0.92 \pm 0(1.08)$ \\
\hline Carbohydrate $(\mathrm{g})$ & $38.35 \pm 0.1$ & Copper $(\mathrm{mg})$ & $0.545 \pm 0.002(0.641)$ \\
\hline Vitamin C (mg) & $9.33 \pm 0.08(10.97)$ & Manganese $(\mathrm{mg})$ & $9.13 \pm 001(10.74)$ \\
\hline $\begin{array}{l}\text { Total carotenoids } \\
\text { (mg) }\end{array}$ & $79 \pm 0.2(9296)$ & Chromium $(\mu \mathrm{g})$ & $70 \pm 0(83.37)$ \\
\hline
\end{tabular}

All value in this table represent the mean $\pm S D(n=4)$. Figures in the parenthesis represent the dry weight values.

\section{Experimental design:}

Four thicknesses $(0.5,1,1.5$ and $2 \mathrm{~cm})$ and five different power levels $(180,360,540,720$ and $900 \mathrm{~W})$. Samples of ginger slices which were individually weighted and positioned at the center of the glass Microwave oven plate (dish). 
Table 2.Thickness and drying load studied.

\begin{tabular}{|l|c|c|c|c|}
\hline Thickness cm & 0.5 & 1 & 1.5 & 2 \\
\hline Drying load kg/m & 4 & 8 & 12 & 15 \\
\hline
\end{tabular}

\section{Measurements:}

\section{Moisture content:}

According to El-Awady, et al. (1993), the moisture content of initial products was determined by drying the product in an electrical oven at 70 ${ }^{\circ} \mathrm{C}$ for 24 hours.

The moisture content on the dry basis $\left(\mathrm{M}_{\mathrm{db}}\right)$ represented as,

$$
M_{d b}=\frac{w_{o}-w_{d}}{w_{d}} \times 100 \quad \%
$$

Where:

$$
\begin{array}{ll}
\text { Wo } & =\text { wet mass of the sample } \\
\mathrm{W}_{\mathrm{d}} & =\text { dry mass of the sample }
\end{array}
$$

\section{Drying rate:-}

Drying rate may be expressed as the thin layer drying equation:-

$$
\frac{\mathrm{dM}}{\mathrm{dt}}=-\mathrm{k}(\mathrm{M}-\mathrm{t} \quad \mathrm{e})
$$

Where, $\mathrm{k}$ and $\mathrm{M}_{\mathrm{e}}$, respectively are the dying constant $\left(\mathrm{s}^{-1}\right)$ and the equilibrium moisture content (\%), $\mathrm{t}$ is the desired time period (s), and $\mathrm{M}_{\mathrm{t}}$ is the instantaneous moisture content which can be estimated as well as the final moisture content throughout the drying process.

\section{Microwave dryer efficiency}

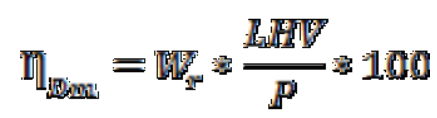

Where : 
PROCESS ENGINEERING

$$
\begin{array}{ll}
\mathrm{W}_{\mathrm{r}} & =\text { water removal } \\
\mathrm{LHV} & =\text { Latent heat of vaporization } 2.25^{*} 10^{3} \\
\mathrm{P} & =\text { Power consumed, } 1350
\end{array}
$$

\section{Total phenolic compound:-}

Total phenolic content was determined by the Folin-Ciocalteu micromethod Saeedeh and Asna, (2007) a $20 \mu \mathrm{L}$ aliquot of extract solution was mixed with $1.16 \mathrm{~mL}$ of distilled water and $100 \mu \mathrm{L}$ of Folin-Ciocalteu's reagent followed by $300 \mu \mathrm{L}$ of $200 \mathrm{~g} \mathrm{~L}-1 \mathrm{Na} 2 \mathrm{CO} 3$ solution. The mixture was incubated in a shaking incubator at $40{ }^{\circ} \mathrm{C}$ for $30 \mathrm{~min}$ and its absorbance at $760 \mathrm{~nm}$ was measured. Gallic acid was used as standard for the calibration curve. Total phenolic content expressed as gallic acid equivalent (GAE) was calculated using the following linear equation based on the calibration curve:

$\mathrm{A}=0.98 \mathrm{C}+9.925 \times 10-3(\mathrm{R} 2=0.9996)$

Where $\mathrm{A}$ is the absorbance and $\mathrm{C}$ is the concentration (mg GAE g-1 dry weight).

\section{Hardnesse:}

Hardness was determined using hardness tester and related penetrometers with quill diameter of $2 \mathrm{~mm}$ which pressed ginger slice until the beginning of the break and then take the reading device value.

\section{Mathematical models:}

The drying curves were fitted with eleven different moisture ratio equations given by several researchers and cited by (Idlimam et al., 2007), as listed in table 3.

\section{Fitting the mathematical models:}

The regression analysis was performed using the statistical computer program. (Data fit 9.0). The goodness of fit of the tested mathematical models to the experimental data was evaluated from the coefficient of determination $\mathrm{R}^{2}$ and the reduced chi-square $\chi^{2}$ between the predicted and experimental values. The higher the R2 values and the lower the $\chi^{2}$ values, the better is the goodness of fit Ertekin and Yaldiz, (2004). The reduced chi-square can be calculated as follow:- 
$\chi^{2}=\frac{\sum_{i=1}^{N}\left(M R_{\exp , i}-M R_{p r e, i}\right)^{2}}{N-n}$

$$
M B E=\frac{1}{N} \sum_{i=1}^{N}\left(M R_{p r e, i}-M R_{\mathrm{exp}, i}\right)
$$

Where:-

$\mathrm{MR}_{\text {exp,i: }}$ : the experimental moisture ratio.

$\mathrm{MR}_{\text {pre, } \mathrm{i}}$ : the predicted moisture ratio.

$\mathrm{N}$ : number of observations

n : number of constants.

MBE: mean bias error was used to determine the quality of the fit.

Table3. Mathematical models applied to the drying curves, (Idlimam et al., 2007).

\begin{tabular}{|c|c|c|}
\hline $\begin{array}{l}\text { Model } \\
\text { number }\end{array}$ & Model name & Model expression \\
\hline 1 & Newton & $\mathrm{MR}=\exp (-\mathrm{k} \cdot \mathrm{t})=\mathrm{e}^{-\mathrm{k} . \mathrm{t}}$ \\
\hline 2 & Page & $\mathrm{MR}=\exp \left(-\mathrm{k} \cdot \mathrm{t}^{\mathrm{n}}\right)=\mathrm{e}^{-\mathrm{k} \cdot \mathrm{tn}}$ \\
\hline 3 & Henderson and Pabis & $M R=a \cdot \exp (-k \cdot t)=a \cdot e^{-k . t}$ \\
\hline 4 & Logarithmic & $\mathrm{MR}=\mathrm{a} \cdot \exp (-\mathrm{k} \cdot \mathrm{t})+\mathrm{c}=\mathrm{a} \cdot \mathrm{e}^{-\mathrm{k} \cdot \mathrm{t}+\mathrm{c}}$ \\
\hline 5 & Two term & $\begin{aligned} \mathrm{MR} & =\mathrm{a} \cdot \exp \left(-\mathrm{k}_{0} \cdot \mathrm{t}\right)+\mathrm{b} \exp \left(-\mathrm{k}_{1} \mathrm{t}\right) \\
& =\mathrm{a} \cdot \mathrm{e}^{-\mathrm{k} 0 . \mathrm{t}}+\mathrm{b} \mathrm{e}^{-\mathrm{k} 1 \mathrm{t}}\end{aligned}$ \\
\hline 6 & Two term exponential & $\begin{aligned} \mathrm{MR} & =\mathrm{a} \cdot \exp (-\mathrm{k} \cdot \mathrm{t})+(1-\mathrm{a}) \exp (-\mathrm{k} \cdot \mathrm{a} \cdot \mathrm{t}) \\
& =a \cdot \mathrm{e}^{-\mathrm{k} \cdot \mathrm{t}}+(1-\mathrm{a}) \mathrm{e}^{-\mathrm{k} \cdot \mathrm{a} . \mathrm{t}}\end{aligned}$ \\
\hline 7 & Wang and Singh & $\mathrm{MR}=1+\mathrm{a} \cdot \mathrm{t}+\mathrm{bt}^{2}=1+\mathrm{a} \cdot \mathrm{t}+\mathrm{bt}^{2}$ \\
\hline 8 & Approximation of diffusion & $\begin{aligned} \mathrm{MR} & =\mathrm{a} \exp (-\mathrm{k} . \mathrm{t})+(1-\mathrm{a}) \exp (-\mathrm{k} \cdot \mathrm{b} \cdot \mathrm{t}) \\
& =\mathrm{a} \mathrm{e}^{-\mathrm{kt} t}+(1-\mathrm{a}) \mathrm{e}^{-\mathrm{kb.b.t}}\end{aligned}$ \\
\hline 9 & $\begin{array}{l}\text { Modified Henderson and } \\
\text { Pabis }\end{array}$ & $\begin{aligned} \mathrm{MR} & =\mathrm{a} \exp (-\mathrm{k} \cdot \mathrm{t})+\mathrm{b} \cdot \exp (-\mathrm{g} \cdot \mathrm{t})+\mathrm{c} \cdot \exp (-\mathrm{h} . \mathrm{t}) \\
& =\mathrm{a} \mathrm{e}^{-\mathrm{k} . \mathrm{t}}+\mathrm{b} \cdot \mathrm{e}^{-\mathrm{g} . \mathrm{t}}+\mathrm{c} \cdot \mathrm{e}^{- \text {h.t }}\end{aligned}$ \\
\hline 10 & Verma & $\begin{aligned} \mathrm{MR} & =\mathrm{a} \exp (-\mathrm{k} . \mathrm{t})+(1-\mathrm{a}) \exp (-\mathrm{g} . \mathrm{t}) \\
& =a \mathrm{e}^{-\mathrm{k} . \mathrm{t}}+(1-\mathrm{a}) \mathrm{e}^{-\mathrm{g} . \mathrm{t}}\end{aligned}$ \\
\hline 11 & Midilli-Kucuk & $\begin{aligned} \mathrm{MR} & =\mathrm{a} \exp \left(-\mathrm{k} \cdot \mathrm{t}^{\mathrm{n}}\right)+\mathrm{b} \cdot \mathrm{t} \\
& =\mathrm{a} \mathrm{e}^{-\mathrm{k} . \mathrm{tn}}+\mathrm{b} \cdot \mathrm{t}\end{aligned}$ \\
\hline
\end{tabular}

Where

MR : moisture ratio, $\mathrm{T}:$ time, $\mathrm{h}$ and $\mathrm{a}, \mathrm{b}, \mathrm{c}, \mathrm{g}, \mathrm{h}, \mathrm{k}, \mathrm{n}:$ constant 


\section{RESULT AND DISCUSSION}

\section{Moisture content:}

Fig.1 (a, b, c and d) show the relation between moisture content of ginger and drying time. Achieving the equilibrium moisture content for ginger by five radiation microwave powers $180,360,540,720$ and $900 \mathrm{~W}$, it required $88,34,24,16$, and $14 \mathrm{~min}$, respectively,at $0.5 \mathrm{~cm}$ thickness while required $116,42,26,16$ and $14 \mathrm{~min}$, respectively at $1 \mathrm{~cm}$ thickness and $118,44,30,18$ and $16 \mathrm{~min}$. at $1.5 \mathrm{~cm}$ thickness and finally 126,48 , 32,18 and $16 \mathrm{~min}$, respectively at $2 \mathrm{~cm}$ thickness.

The moisture content of the ginger slices was very high during the initial phase of the drying which resulted in high drying rates due to the higher moisture diffusion.
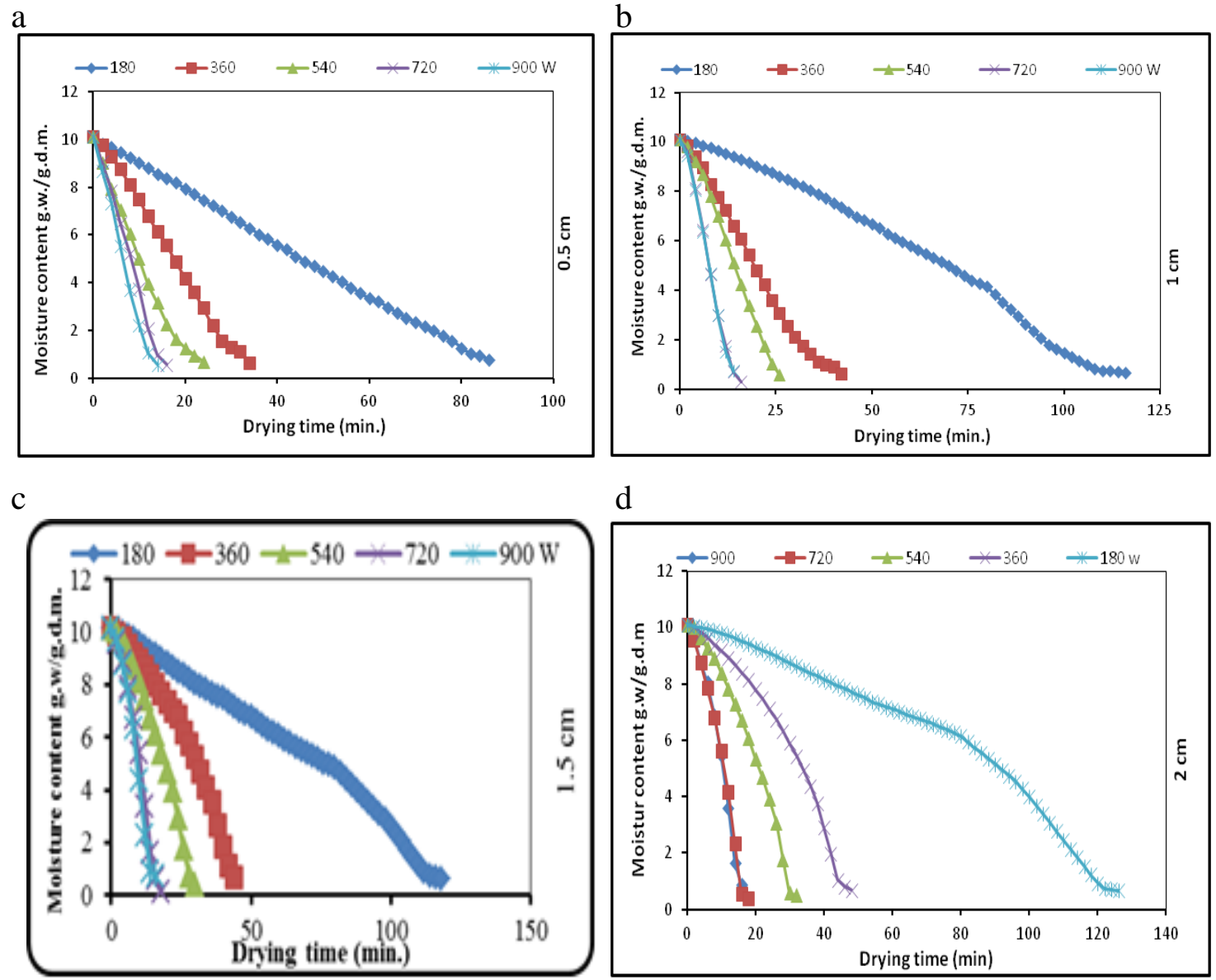

Fig.(1): Variation of drying time with change in moisture content of ginger by microwave 


\section{Drying rate:}

At the beginning when moisture content was high, the drying rate under all drying conditions increased with time. This is due to high amount of free moisture availability, which was easily removed in the initial stage of drying. Fig.2(a) shows the change of drying rate of ginger slices at the thickness of $0.5 \mathrm{~cm}$. clear difference in drying rate was found among the different power in microwave drying and all the drying rate apparently decreased. The average drying rates at $10 \mathrm{~min}$. from the total drying time was $1.57,1.27,1.02,0.52$, and $0.22 \mathrm{~g}$. w/g. d. m. min for the different powers 900, 720, 540, 360 and $180 \mathrm{~W}$ respectively. A constant rate period was followed by a falling rate period in which moisture content decreased to $4.56,3.88,2.77,2.2$ and $1.7 \mathrm{~g}$. w/g. d. m. for the different microwave powers $180,360,540,720$ and $900 \mathrm{~W}$, respectively.

a

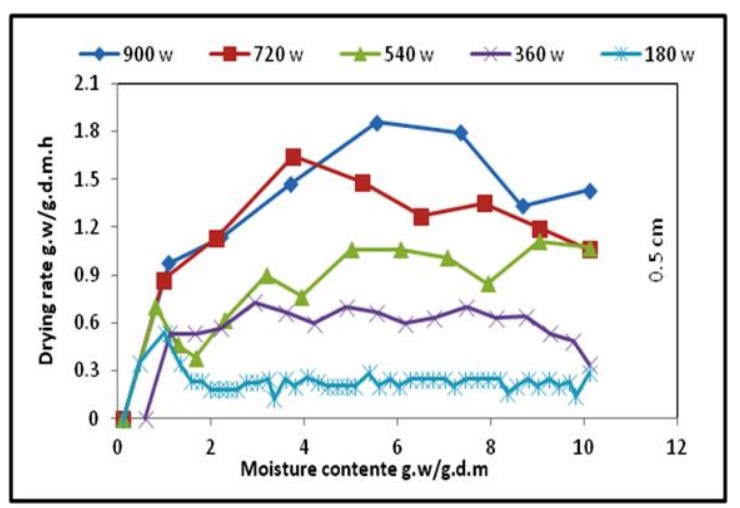

C

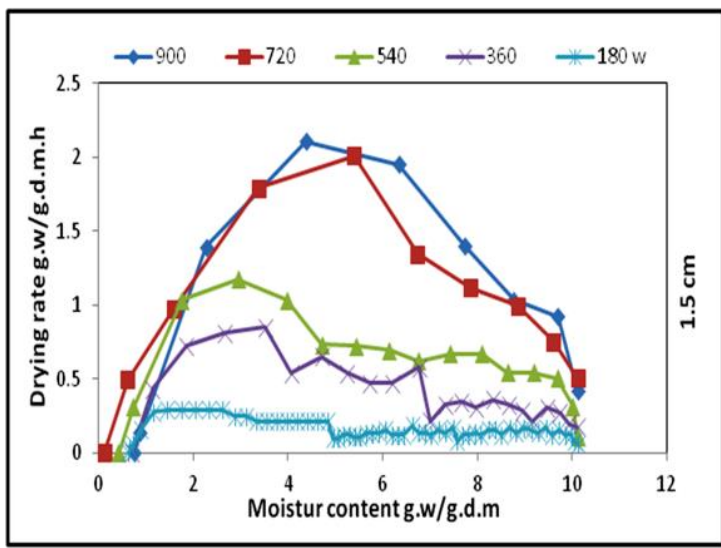

b

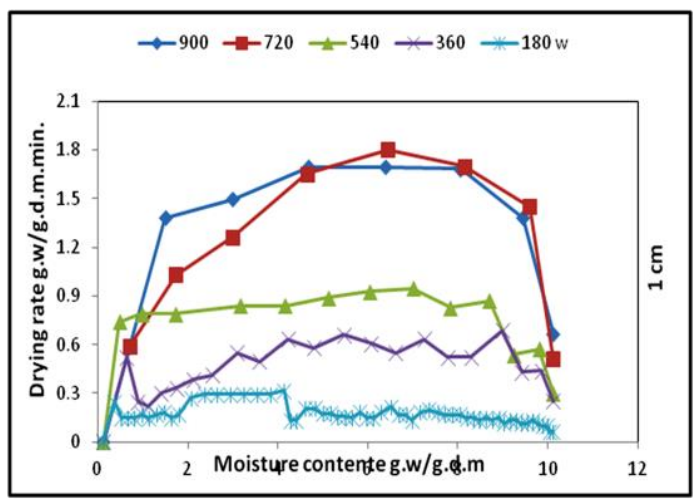

$\mathrm{D}$

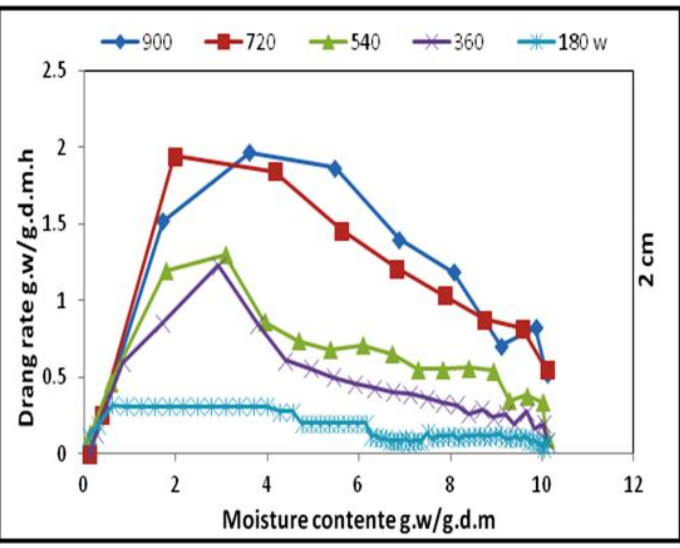

Fig. (2)Variation of drying rate with change in moisture content by microwave drying 
The change of ginger drying rates at $1 \mathrm{~cm}$ thickness are shown in fig. 2 (b). The average of drying rates at constant rate period ranged from 0.712 to $0.045 \mathrm{~g}$. w/g. d. m. min for the different studied powers after $10 \mathrm{~min}$ of drying time, it can be seen remarkable difference in drying rate between the different powers in microwave drying and all the drying rate apparently decreased. A constant rate period was followed by a falling rate period in which moisture content decreased to 4.55, 4.03, 3.66, 2.06 and $2.03 \mathrm{~g}$. w/g. d. m. for the different microwave powers $180,540,360$, 900 and $720 \mathrm{~W}$, respectively.

Fig.2(c) revealed the changes of ginger drying rates dried in microwave powers at $1.5 \mathrm{~cm}$ thickness Clear differences were observed in drying rates among the different powers in microwave drying and all the drying rate apparently decreased.

The drying rates average at the constant rate period could be arranged in the following decreasing order $0.57,0.47, .0 .2,0.12$ and $0.054 \mathrm{~g}$. w/g. d. $\mathrm{m}$. min. for the different powers 900, 720, 540, 360 and $180 \mathrm{~W}$, respectively after $4 \mathrm{~min}$. from the total drying time. A constant rate period was followed by a falling rate period in which moisture content decreased to $3.02,2.88,2.7,2.2$ and $2.15 \mathrm{~g}$. w/g. d. m. for the different powers $360,180,540,900$ and $720 \mathrm{~W}$, respectively.

Fig.2(d) represent the ginger slices ( $2 \mathrm{~cm}$ thickness) drying rate of Clear differences in drying rate were observed among the different powers in microwave drying and also all the drying rate apparently decreased. On the drying conditions, the average drying rates at the constant rate period was ranged from 0.46 to $0.031 \mathrm{~g}$. w/g. d. m. min for the different powers $900,720,540,360$ and $180 \mathrm{~W}$, respectively, at $4 \mathrm{~min}$ from the total drying time.

A constant rate period followed by a falling rate period in which moisture content decreased to 3.15, 3.0, 2.8, 2.52 and 2.28 g. w/g. d. m. for the different powers $180,360,540,900$ and $720 \mathrm{~W}$ respectively. The highest average drying rate was $0.788 \mathrm{~g} / \mathrm{min}$ at $0.5 \mathrm{~cm}$ thickness and $900 \mathrm{~W}$. From the results, at different thicknesses, the drying rate increased by decreasing the thickness. This is due to high amount of free moisture availability, which was easily removed in the initial stage of drying. Total phenolic compound 
Table (4) shows the total phenols content of fresh and dried ginger rhizome. The fresh ginger phenolic content $(0.40 \mathrm{mg}$ GAE/g d.W.) was affected by changing the microwave power and ginger thickness. The phenolic content of the microwave dried ginger slices ranged from (1.5, 2 $\mathrm{cm}$ thickness) which dried by microwave could be arranged from 0.14 to $0.72 \mathrm{mg} \mathrm{GAE} / \mathrm{g}$. d. m.. The highest phenolic contents was detected in the slices dried at 900 Watt at $1.5 \mathrm{~cm}$ slices thickness while the lowest was recorded in the slices dried $180 \mathrm{~W}$ att at $2 \mathrm{~cm}$ thickness.

Table (4): Total phenols content of fresh and microwave dried ginger

\begin{tabular}{|c|l|c|c|c|c|c|}
\hline Thickness & Fresh & \multicolumn{5}{|c|}{ Microwave power W } \\
\cline { 3 - 7 } cm. & $\mathrm{mg} / 100 \mathrm{~g}$ & 180 & 360 & 540 & 720 & 900 \\
\hline 0.5 & 0.40 & 0.35 & 0.15 & 0.32 & 0.20 & 0.18 \\
\hline 1 & 0.40 & 0.19 & 0.26 & 0.19 & 0.30 & 0.49 \\
\hline 1.5 & 0.40 & 0.29 & 0.27 & 0.37 & 0.20 & 0.72 \\
\hline 2 & 0.40 & 0.14 & 0.30 & 0.36 & 0.29 & 0.58 \\
\hline
\end{tabular}

\section{Effect of microwave drying on ginger hardness}

The fresh ginger presented average hardness ranged from 0.5 to 1 $\mathrm{kg} / \mathrm{cm}^{2}$ and then increased gradually with decreasing in moisture content at all microwave drying powers and all thickness. As shown in table (5) the higher value $\left(6 \mathrm{~kg} / \mathrm{cm}^{2}\right)$ occurred when using all microwave drying powers at thickness 1.5 and $2 \mathrm{~cm}$ which was higher than the fresh ginger by $80 \%$.The lowest value $\left(5.5 \mathrm{Kg} / \mathrm{cm}^{2}\right)$ occurred when using 180 and $360 \mathrm{~W}$ microwave drying powers at $0.5 \mathrm{~cm}$ thickness which was higher than other in fresh ginger by $90 \%$.

Table (5) Hardness of fresh and microwave dried ginger $\left(\mathrm{kg} / \mathrm{cm}^{2}\right)$

\begin{tabular}{|c|c|c|c|c|c|c|}
\hline $\begin{array}{c}\text { Thickness } \\
\mathrm{cm} .\end{array}$ & Fresh & \multicolumn{6}{|c|}{ Microwave power W } \\
\cline { 3 - 7 } & & 180 & 360 & 540 & 720 & 900 \\
\hline 0.5 & 0.5 & 5.5 & 5.5 & 5.6 & 6 & 6 \\
\hline 1 & 0.5 & 5.5 & 5.7 & 5.9 & 6 & 6 \\
\hline 1.5 & 0.7 & 5.7 & 5.8 & 6 & 6 & 6 \\
\hline 2 & 1 & 5.9 & 5.9 & 6 & 6 & 6 \\
\hline
\end{tabular}




\section{Drying Efficiency:}

Fig.3 (a, b, c and d), describe the relation between the drying efficiency of ginger and drying time at the four studied thicknesses $(0.5,1,1.5$ and $2 \mathrm{~cm}$ ), and different microwave powers (180, 360, 540, 720 and $900 \mathrm{~W}$ ). The drying efficiency was always relative low at the beginning of the drying process due to decrease in drying rate. The drying efficiency increased by increasing both of thickness and microwave power. The highest efficiency was $78 \%$ at $2 \mathrm{~cm}$ thickness and 720, $900 \mathrm{~W}$. While the lowest was less than $0.10 \%$ at $180 \mathrm{~W}$ and all studied thicknesses except at $2 \mathrm{~cm}$. Furthermore, microwave power $(180 \mathrm{~W})$ took the longest period time, this means more power consumption.

a

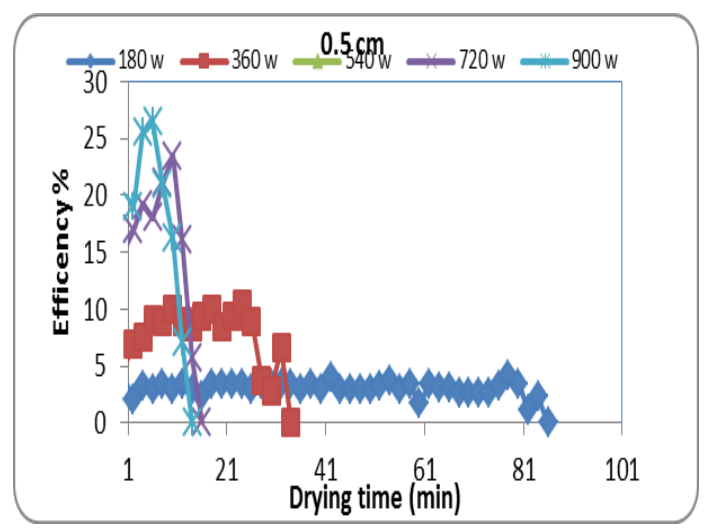

C

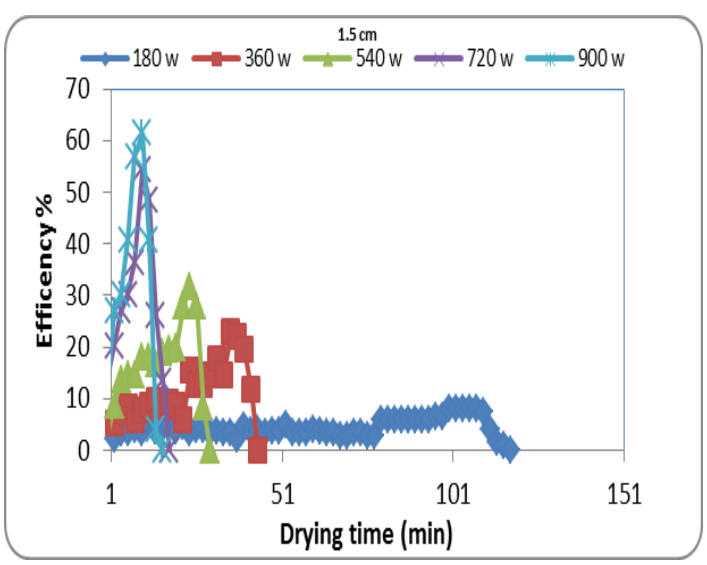

$\mathrm{b}$

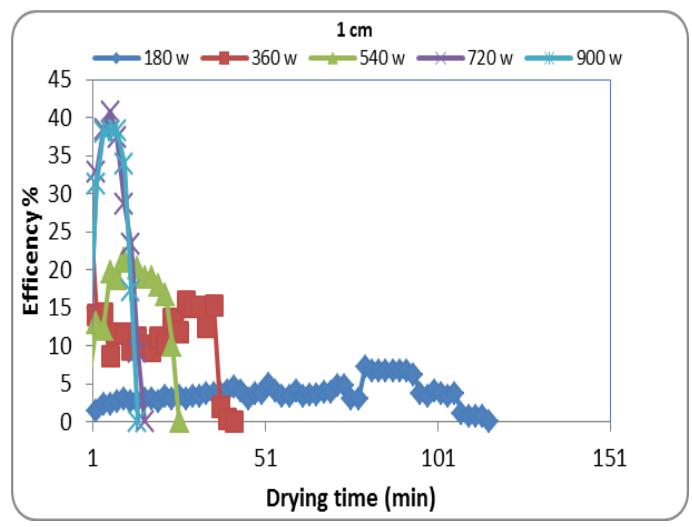

d

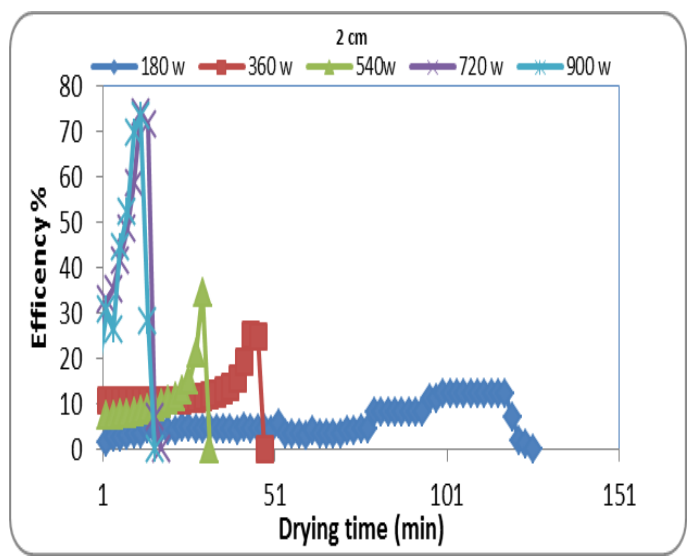

Fig. (3): Relation between the microwave efficiency and drying time of ginger 


\section{Consumption energy during drying ginger roots $(\mathrm{KJ})$}

Table (6) shows the total consumption energy during drying of ginger by variant microwave power $180,360,540,720$ and $900 \mathrm{~W}$ at the studied four thicknesses $0.5,1,1.5$ and $2 \mathrm{~cm}$. The highest amount of energy consumption was $10.2 \mathrm{MJ}$ at $180 \mathrm{~W}$ of microwave drying power and $2 \mathrm{~cm}$ thickness, while the lowest amount of energy consumption was $1.1 \mathrm{MJ}$ at $900 \mathrm{~W}$ powers and $0.5,1 \mathrm{~cm}$ thicknesses.

Table (6): Total energy consumption (MJ) during drying ginger by microwave drying .

\begin{tabular}{|c|c|c|c|c|c|}
\hline \multirow{2}{*}{$\begin{array}{c}\text { Thickness } \\
(\mathrm{cm})\end{array}$} & \multicolumn{5}{|c|}{ Microwave power (W) } \\
\cline { 2 - 6 } & 900 & 720 & 540 & 360 & 180 \\
\hline 0.5 & 1134 & 1296 & 1944 & 2754 & 6966 \\
\hline 1 & 1134 & 1296 & 2106 & 3402 & 9396 \\
\hline 1.5 & 1296 & 1458 & 2430 & 3564 & 9558 \\
\hline 2 & 1296 & 1458 & 2592 & 3888 & 10206 \\
\hline
\end{tabular}

\section{Mathematical models:}

Drying curves were simulated using empirical models of reduced moisture content. These empirical models coming from the fundamental diffusion models that were generally suitable for drying fruits. The drying data as the moisture ratio (MR) versus drying time were fitted to the eleven drying models. The predicted (MR) of the ginger was obtained using the Data fit computer program. Table (3.4) shows the drying model coefficients and the comparison criteria used to evaluate goodness of fit, namely the coefficient of determination $\left(\mathrm{R}^{2}\right)$, the reduced Chi-square $\left(\chi^{2}\right)$, and mean bias error (MBE). For microwave dryer, the values of $\mathrm{R}^{2}, \chi^{2}$, and MBE for models ranged from 0.9871 to $0.9988,4.1334 \mathrm{e}-9$ to, 0.00254 and $-7.288 \mathrm{e}-4$ to, 0.014257 respectively. According to table (7) the Verma et al model showed good agreement with the experimental data and gave the best result for ginger samples at $180 \mathrm{~W}$ of microwave power and $0.5 \mathrm{~cm}$ thickness. 
Table (7): Modeling of moisture ratio according to drying time for ginger by mic. drying.

\begin{tabular}{|c|c|c|c|c|c|c|c|c|c|c|}
\hline \multirow[t]{2}{*}{ Thick. } & \multirow[t]{2}{*}{ Power(w) } & \multirow[t]{2}{*}{ model } & \multicolumn{5}{|c|}{ Model parameters ( Coefficients) } & \multirow[t]{2}{*}{$\mathrm{R}^{2}$} & \multirow[t]{2}{*}{$\chi^{2}$} & \multirow[t]{2}{*}{ MBE } \\
\hline & & & a & $\mathrm{b}$ & C-g & $\mathrm{k}$ & $\mathrm{n}$ & & & \\
\hline \multirow{4}{*}{$0.5 \mathrm{~cm}$} & 180 & V & -0.3145 & & $6.4 \mathrm{e}-3$ & $-9.72 e-3$ & & 0.998 & $1.5 \mathrm{e}-5$ & $-5.36 e-4$ \\
\hline & 360 & $\mathrm{~L}$ & 15.6826 & & -14.64 & $2.18 \mathrm{e}-3$ & & 0.998 & $4.1 \mathrm{e}-9$ & $1.38 \mathrm{e}-5$ \\
\hline & 540 & $\mathrm{~W}$ & $-5.87 e-2$ & $7.12 \mathrm{e}-4$ & & & & 0.997 & $6.5 \mathrm{e}-5$ & $-2.03 e-3$ \\
\hline & 720 & $\mathrm{~L}$ & 15.6212 & & -14.59 & $4.32 \mathrm{e}-3$ & & 0.996 & $1.4 \mathrm{e}-5$ & 0.00104 \\
\hline \multirow{5}{*}{1} & 900 & $\mathrm{~L}$ & 3.70905 & & -2.688 & $2.36 \mathrm{e}-2$ & & 0.995 & $6.8 \mathrm{e}-5$ & $1.04 \mathrm{e}-4$ \\
\hline & 180 & W & $-5.15 e-3$ & $-3.2 e-5$ & & & & 0.997 & $1.4 \mathrm{e}-4$ & -.00155 \\
\hline & 360 & $\mathrm{P}$ & & & & $4.36 \mathrm{e}-3$ & 1.737 & 0.996 & 7.7e-4 & $5.65 \mathrm{e}-3$ \\
\hline & 540 & $\mathrm{P}$ & & & & $2.00 e-3$ & 2.249 & 0.990 & 0.002 & 0.01166 \\
\hline & 720 & P & & & & $9.27 e-3$ & 2.210 & 0.992 & 0.001 & 0.01272 \\
\hline \multirow{6}{*}{1.5} & 900 & W & $-5.84 \mathrm{e}-2$ & $-1.4 \mathrm{e}-3$ & & & & 0.993 & 4.0e-4 & 0.00616 \\
\hline & 180 & W & $-5.14 \mathrm{e}-3$ & $-2.4 e-5$ & & & & 0.993 & $3.9 \mathrm{e}-4$ & $2.51 \mathrm{e}-3$ \\
\hline & 360 & $\mathrm{~W}$ & $-6.46 e-3$ & $-3.4 e-4$ & & & & 0.996 & $1.9 \mathrm{e}-4$ & 0.00275 \\
\hline & 540 & W & $-1.30 \mathrm{e}-2$ & $-7.1 \mathrm{e}-4$ & & & & 0.997 & $7.7 e-5$ & -0.0020 \\
\hline & 720 & $\mathrm{P}$ & & & & $2.19 \mathrm{e}-3$ & 2.534 & 0.990 & 0.002 & 0.01425 \\
\hline & 900 & $\mathrm{P}$ & & & & $2.160 \mathrm{e}-3$ & 2.636 & 0.992 & 0.001 & 0.00833 \\
\hline \multirow{5}{*}{$2 \mathrm{~cm}$} & 180 & W & $-2.2 \mathrm{e}-3$ & $-4.2 e-5$ & & & & 0.987 & 0.001 & 0.00427 \\
\hline & 360 & V & -.29460 & & $-2 . e-3$ & $-3.39 \mathrm{e}-2$ & & 0.996 & $1.8 \mathrm{e}-7$ & $5.12 \mathrm{e}-5$ \\
\hline & 540 & W & $-9.93 e-3$ & $-6.8 e-4$ & & & & 0.998 & $1.0 e-5$ & $-7.28 \mathrm{e}-4$ \\
\hline & 720 & W & $-3.05 e-2$ & $-1.6 e-3$ & & & & 0.986 & $1.2 \mathrm{e}-4$ & -0.0031 \\
\hline & 900 & W & $-1.71 \mathrm{e}-2$ & $-2.9 \mathrm{e}-3$ & & & & 0.997 & $8.6 e-5$ & -0.0027 \\
\hline
\end{tabular}

\section{CONCLUSION:}

The drying time of ginger slices could be reduced by using the microwave power at both 720 and $900 \mathrm{~W}$ with a $0.5 \mathrm{~cm}$ thickness. The highest efficiency was $78 \%$ at 720 and $900 \mathrm{~W}$ with $2 \mathrm{~cm}$ thickness. The 
highest phenol content in dried ginger by microwave was $0.72 \mathrm{mg} / \mathrm{g}$ solid material when the power was $900 \mathrm{~W}$ and $1.5 \mathrm{~cm}$ thickness. Veirma et al model can be used to describe the behavior of microwave drying of ginger, which gave the best results at 180 Watts and $0.5 \mathrm{~cm}$ thickness.

\section{REFERENCES}

Chan, E. W. C., Lim, Y. Y., Wong, L. F., Lianto, F. S., Wong, S. K., Lim, K. K., (2008).Antioxidant and tyrosinase inhibition properties of leaves and rhizomes of ginger species. Food Chemistry, 109, 477-483.

El-Awady, M. N., Mohamed, S. A., El-Sayed, A. S. and Hassanain, A. A. (1993).Utilization of solar energy for drying processes of agricultural products. Misr, J. Ag. Eng., 10(4):794-804.

Ertekin, C. and Yaldiz, O. (2004). Drying of eggplant and selection of a suitable hin layer-drying model. Journal of Food Engineering;(53): 349-359.

Idlimam, A.; Ethmane Kane, C. S. and Kouhila, M. (2007). Single layer drying behaviour of grenade peel in a forced convective solar dryer .Revue des Energies Renouvelables , 10 (2): 191 - 203.

Li, Z., Raghavan, G.S.V., Wang, N., (2010) Apple volatiles monitoring and control in microwave drying. LWT-Food Science and Technology 43, 684-689.

Rahman H., R. Karuppaiyan, K. Kishor, and R. Denzongpa, (2009)."Traditional practices of ginger cultivation in north east India,'Indian Journal of Traditional Knowledge, vol. 8, no. 1, pp. 23-28,.

Saeedeh A and Asna U (2007).Antioxidant properties of various solvent extracts of mulberry (Morusindica L.) leaves. Food Chem 102:1233-1240. 
Shirin Adel P. R.* and Jamuna Prakash (2010). Chemical composition and antioxidant properties of ginger root (Zingiber officinale). Journal of Medicinal Plants Research Vol. 4(24), pp. 2674-2679

Torringa E; Esveld E; Scheewe I; van den Berg R; Bartels P (2001) Osmotic dehydration as a pre-treatment before combined microwave-hot-air drying of mushrooms. Journal of Food Engineering, 49, 185-191.

Zhang, M., Tang, J., Mujumdar, A.S., Wang, S., 2006. Trends in microwave-related drying of fruits and vegetables. Trends in Food and Technology 17, 524-534.

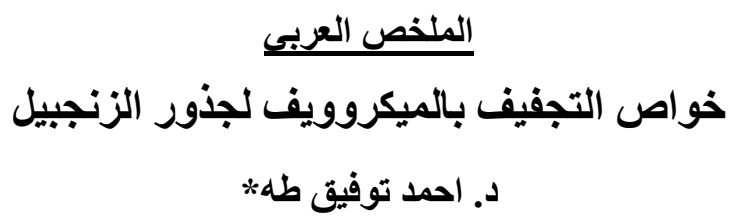

يهدف البحث الي دراسة كفاءة التجفيف باستخدام طاقة الميكرويف وتاثيرها علي المواصفات

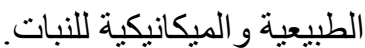

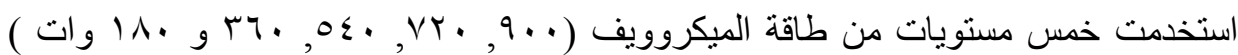

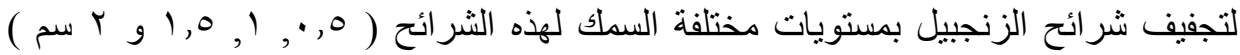
تضمن البحث دراسة خواص التجفيف ( المحتوى الرطوبي, زمن التجفيف, معدل التجفيف و

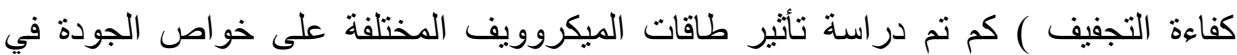
الزنجبيل وكانت اهم النتائج المتحصل عليها كما يلي:

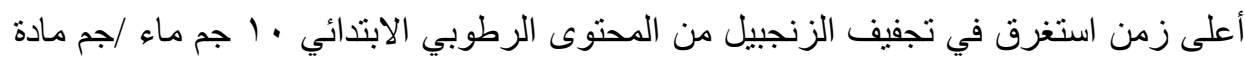

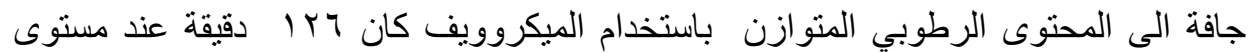

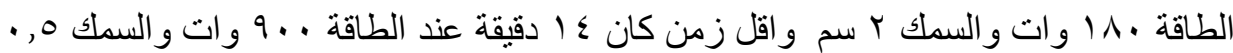

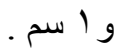

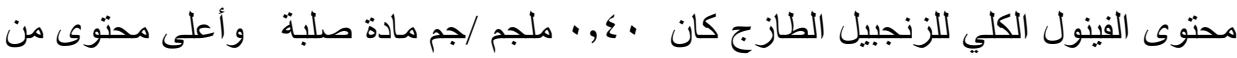
الفينول في الزنجبيل المجفف بواسطة الميكروويف كان Vr, . ملغ /جم مادة صلبة عند الطاقة

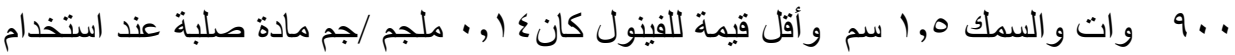

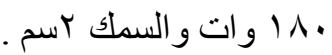

قسم الهندسة الزراعية ـ كلية الزراعة - جامعة المنوفية 


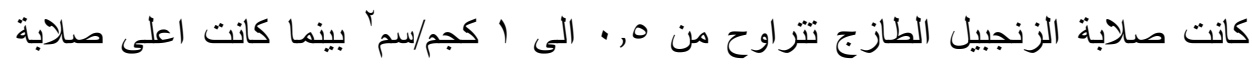

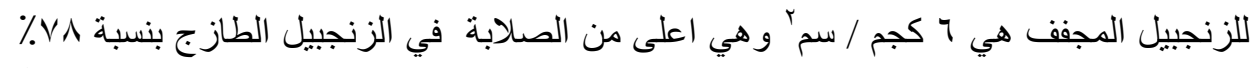

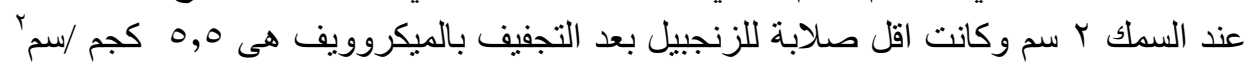

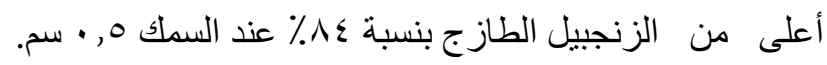

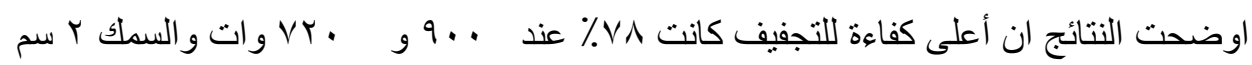

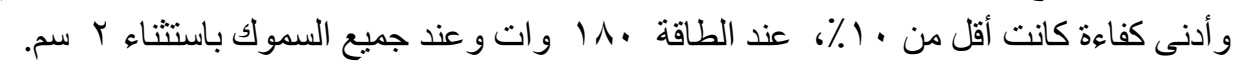

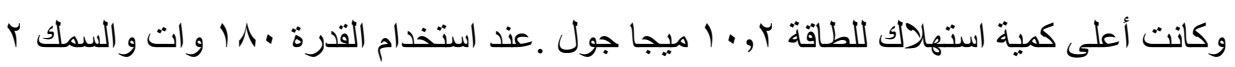

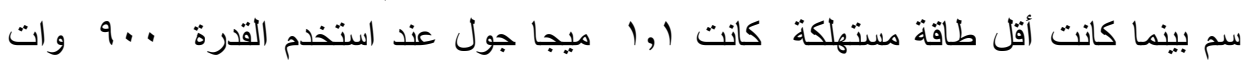
و السمك ه, . و و سم. سم الت طل 